\title{
The reverse genetics of HTLV-1 infected patients
}

\author{
Luiz C Alcantara Jr ${ }^{1,2,3^{*}}$, Izabela Bialuk ${ }^{1,4}$, Maria F de Castro-Amarante ${ }^{1}$, Cody Buchmann ${ }^{1}$, Sebastien Chevalier ${ }^{1,5}$, \\ Risaku Fukumoto ${ }^{1}$, Vibeke Andresen ${ }^{1}$, Cynthia Pise-Masison ${ }^{1}$, Steven Jacobson ${ }^{6}$, Bernardo Galvao-Castro ${ }^{2,3}$, \\ Antoine Gessain ${ }^{7}$, Genoveffa Franchini ${ }^{1}$
}

From 15th International Conference on Human Retroviruses: HTLV and Related Viruses Leuven and Gembloux, Belgium. 5-8 June 2011

The HTLV-1 ORF-1-encoded p12 protein induces T-cell activation and proliferation, while the cleaved $\mathrm{p} 8$ protein downregulates TCR signaling. In this study, we investigated whether there is a correlation between genetic variation within ORF-1 and the clinical status or proviral load in HTLV-1 infected individuals. The ORF-1 gene was amplified by PCR from PBMCs of 163 HTLV1-infected patients (85 carriers, 78 HAM/TSP) from different geographical regions and a total of 1,640 clones were sequenced. The majority of the patients $(73 \%)$ carried mutations in ORF-1 that resulted in the expression of more p 12 than p8 (50\% Carriers and 50\% HAM/ TSP). The highest genetic variability within ORF-1 was found in the two transmembrane domains of the protein. Of interest, a subclass of mutations was found more frequently in HAM/TSP patients compared to Carriers. While higher proviral loads were found in HAM/TSP patients compared to Carriers ( $\mathrm{p}=0.0001$ ), no correlation between proviral load and the ORF-1 isoform expressed was observed (mainly p12, both p12 and $\mathrm{p} 8$, or mainly $\mathrm{p} 8$ ). Currently experiments are aimed at determining the significance of these mutations in ORF1 function in regard to T-cell activation and proliferation. In addition, mutations will be characterized for their role in viral infectivity and transmission rates ex vivo and in a rhesus macaque model. Determining the effects of ORF-1 mutants on viral replication, spread and latency will provide insight into the pathogenesis of HTLV-1 infection.

\section{Author details}

${ }^{1}$ Animal Models and Retroviral Vaccines Section, National Cancer Institute, Bethesda, MD, 20892, USA. ${ }^{2}$ Oswaldo Cruz Foundation Salvador, Bahia, Brazil.

\footnotetext{
* Correspondence: Ialcan@bahia.fiocruz.br

'Animal Models and Retroviral Vaccines Section, National Cancer Institute, Bethesda, MD, 20892, USA

Full list of author information is available at the end of the article
}

${ }^{3}$ HTLV Center/ Bahia School of Medicine and Public Health, Salvador, Bahia, Brazil. ${ }^{4}$ Department of General and Experimental Pathology, Medical University of Białystok, Białystok, 15-222, Poland. ${ }^{5}$ Unité de Virologie Humaine, Département de Biologie, Ecole Normale Supérieure Lyon,Lyon, France. ${ }^{6}$ Viral Immunology Section, Neuroimmunology Branch, National Institute of Neurological Disorders and Stroke, Bethesda, MD, 20892, USA. ${ }^{7}$ Unité d'Epidémiologie et Physiopathologie des Virus Oncogènes, Institut Pasteur, Paris, France.

Published: 6 June 2011

doi:10.1186/1742-4690-8-S1-A193

Cite this article as: Alcantara et al.: The reverse genetics of HTLV-1 infected patients. Retrovirology 2011 8(Suppl 1):A193.

Submit your next manuscript to BioMed Central and take full advantage of:

- Convenient online submission

- Thorough peer review

- No space constraints or color figure charges

- Immediate publication on acceptance

- Inclusion in PubMed, CAS, Scopus and Google Scholar

- Research which is freely available for redistribution

Submit your manuscript at www.biomedcentral.com/submit
() Biomed Central

\section{Biomed Central}

